\title{
Correction: Phosphorylation Affects DNA-Binding of the Senescence-Regulating bZIP Transcription Factor GBF1. Plants 2015, 4, 691-709
}

\author{
Anja Smykowski, Stefan M. Fischer and Ulrike Zentgraf * \\ ZMBP, General Genetics, University of Tuebingen, Auf der Morgenstelle 32, Tuebingen 72076, Germany; \\ smyka@gmx.net (A.S.); stefan.fischer@zmbp.uni-tuebingen.de (S.M.F.) \\ * Correspondence: ulrike.zentgraf@zmbp.uni-tuebingen.de
}

Academic Editor: Milan S. Stankovic

Received: 23 August 2016; Accepted: 25 August 2016; Published: 1 September 2016

The authors wish to make the following corrections to their paper [1].

1. In Section 4.3 (Recombinant Proteins) CKII 2 (AT3G50000) cDNA was also cloned into pUC Spyne/Spyce for expression.

2. In Section 4.7. (In Vitro Kinase Assay), we used 5 and $15 \mu \mathrm{L}$ of the protein extract containing the substrate equivalent to approx. 15 and $45 \mu \mathrm{g}$ of total protein respectively, not 25 and $50 \mu \mathrm{g}$, and the reaction buffer contained only $100 \mu \mathrm{M}$ ATP as indicated in the legend of Figure 1.

3. In Section 4.8. (qRT-PCR), unfortunately, the wrong method for the expression analyses was provided. We did not use qRT-PCR but semi-quantitative RT-PCR as indicated in the legend of Figure 4C. RNA was isolated from pooled leaf material with a PURESCRIPT RNA Isolation Kit (Gentra, Biozym) and cDNA was polymerized using the iScript ${ }^{\mathrm{TM}} \mathrm{cDNA}$ Synthesis Kit (Bio-Rad, Munich, Germany) as indicated previously. Further, RT-PCR, rather than qRT, was performed using primer pairs as listed in Table 1 . A low cycle number ( 25 cycles) was chosen so that the PCR did not reach saturation phase. Subsequently, RT-PCR products were separated on 1\% agarose gels. The band intensity was quantified using the NIH image program (Scion Image, Scion Corporation). Expression was normalized to ACTIN2 as previously indicated.

4. In Figure 2A error bars represent $\mathrm{SE}$ not $\mathrm{SD}$, and in Figure $2 \mathrm{C}$ only two replicates were taken into account, so that the statement at the end of the figure legend that the error bars indicate SD of 3-6 independent replicates is not correct for all parts of the figure.

We apologize for any inconvenience caused to readers. The manuscript will be updated and the original will remain available on the article webpage.

\section{Reference}

1. Smykowski, A.; Fischer, S.M.; Zentgraf, U. Phosphorylation Affects DNA-Binding of the Senescence-Regulating bZIP Transcription Factor GBF1. Plants 2015, 4, 691-709. [PubMed]

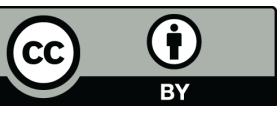

(C) 2016 by the authors; licensee MDPI, Basel, Switzerland. This article is an open access article distributed under the terms and conditions of the Creative Commons Attribution (CC-BY) license (http://creativecommons.org/licenses/by/4.0/). 